\title{
Nursery function of Wadden Sea tidal flats for the brown shrimp Crangon crangon
}

\author{
B. R. Kuipers and R. Dapper
}

Netherlands Institute for Sea Research, Postbox 59, 1790 AB den Burg, Texel, The Netherlands

\begin{abstract}
The significance of the tidal zone as nursery area for the brown shrimp Crangon crangon became evident during a study on density and size-distribution of predator populations on a $50 \mathrm{~km}^{2}$ tidal flat in the western Wadden Sea (The Netherlands). A clear picture of the nursery system and its function in the annual cycle of brown shrimp is obtained when nursery population-data are combined with experimental growth rates in juvenile C. crangon and their dependence on temperature and body size. Shrimp brood settles in the area during February-August with main arrival during April, May and June; it leaves the tidal zone, at a body length of ca. $30 \mathrm{~mm}$, during July-September. At the end of the year the majority of the new shrimp generation reaches maturity, after which winter spawning leads to settlement of new brood in spring again. The annual cycle thus obtained fits well in the seasonal pattern of commercial shrimp catches in the area. The predominance of winter spawning and the low effect of summer-egg production is explained by the seasonal temperature cycle and its effect on the development of the juveniles at our latitude, as well as by a specific seasonal pattern of predation pressure on shrimp brood in the tidal zone. Spawning cycles in $C$. crangon along other parts of the European continental coast are discussed
\end{abstract}

\section{INTRODUCTION}

\section{General aspects}

Due to its economic importance, a variety of publications exist on most life stages of Crangon crangon. In an extensive review Tiews (1970) summarized the biogeographical characteristics of the distribution area of the species as follows: 'Main distribution in highly productive estuaries with strong tidal movements of brackish water masses in the temperate climatic zone of Europe between $45^{\circ}$ and $57^{\circ} \mathrm{N}$ on sandy and muddy substratum'.

The preference of Crangon crangon for estuarine areas, its seasonal migration that brings it into these shallow productive parts of the coastal zone in spring, and the movement back to deeper water when the estuaries cool down again in autumn, have been known for a long time from the commercial fisheries and from fisheries research (Havinga, 1930; Tiews, 1954; Meyer-Waarden and Tiews, 1957; Boddeke, 1976). Coastal areas with a much less pronounced estuarine character, e.g. those outside the Dutch and Belgian sandy beach zone, are also important shrimping grounds (Redant, 1978).
Apart from the more general 'feeding' migrations of Crangon crangon, there are short-term movements connected with spawning and egg carriage that seem to depend to a large extent on changes in environmental factors such as water temperature and salinity; therefore they vary not only spatially but also seasonally (Verwey, 1956, 1958; Spaargaren, 1971; Boddeke. 1976). Because of these migrations, growth rates of $C$. crangon are difficult to determine from data collected at fixed sampling stations. Measurements on growth rates in the field are even more obscured by another factor: Berried females, planktonic larvae and settling postlarval juveniles do not occur peakwise once a year, but are recorded over longer periods of time. Clear-cut cohorts or age-groups do not exist. On the contrary, the C. crangon population is gradually (in 'brood waves') replaced by new generations.

Most papers on the population biology of Crangon crangon agree on the following very general concept of its life-cycle:

- Along the continental coasts of Europe Crangon crangon spawns in all months of the year, with larger eggs during winter (November-March) than during summer (April-September) (Boddeke, 1982).

- Egg-development lasts 3.5 to $13 \mathrm{wk}$ depending on 
the water-temperature $\left(16\right.$ to $\left.5^{\circ} \mathrm{C}\right)$, after which the 5 pelagic stages develop over another $5 \mathrm{wk}$.

- At an average length of $4.7 \mathrm{~mm}$, post-larval Crangon crangon settle on the sea bed and join the benthic food web.

- Maturation, at a body length between 40 and $50 \mathrm{~mm}$, is reached after a period of juvenile growth that lasts, according to different authors, from 4 mo to 2 yr.

- After its first spawning Crangon crangon lives most likely 1 , but according to several authors 2 , or even 3 more years during which it alternatively spawns and grows (to a maximum size of ca. $80 \mathrm{~mm}$ ). Such maximum length, however, is rarely reached because Crangon crangon is a favoured prey for many fish species and is often the subject of specialized fisheries.

\section{Balgzand tidal nursery}

So far most studies have concentrated on largersized shrimp, present in commercial shrimp catches, and on planktonic stages. Relatively little attention has been devoted to the early post-larval stages, which are largely absent in the catches of shrimp boats, presumably due to mesh-size selection. However, as shown in earlier studies (Janssen and Kuipers, 1980; Kuipers and Dapper, 1981) such absence can also be explained by segregation of smallest shrimp $(<35 \mathrm{~mm}$ ) in the littoral zone, i.e. outside the fishing area. On a $50 \mathrm{~km}^{-2}$ tidal flat area (Balgzand), in the western part of the Wadden Sea (Fig. 1), the great majority of the shrimp present were found to be smaller than $35 \mathrm{~mm}$ in total length, whereas in the nearby subtidal region most shrimp were larger than $30 \mathrm{~mm}$ (Janssen and Kuipers, 1980). Abundance estimates and length composition of shrimp in the period April-October indicated, that settlement of larvae occurred on the tidal flats throughout the warmer part of the year, with peak settlement in May-June. During summer and autumn there seems to be a constant shift of 30 to $35 \mathrm{~mm}$ long shrimp towards the subtidal area (Kuipers and Dapper, 1981). The data therefore suggest that the tidal flats in the Wadden Sea act as important nursery area's for brown shrimp, comparable to the situation in plaice Pleuronectes platessa (Kuipers, 1977). The earlier reported shrimp studies on Balgzand concentrated on migration, food consumption and production of the juvenile shrimp population

\section{METHODS}

From Balgzand data (1981), the production of Crangon crangon in the nursery was estimated with a computer programme, originally developed to estimate
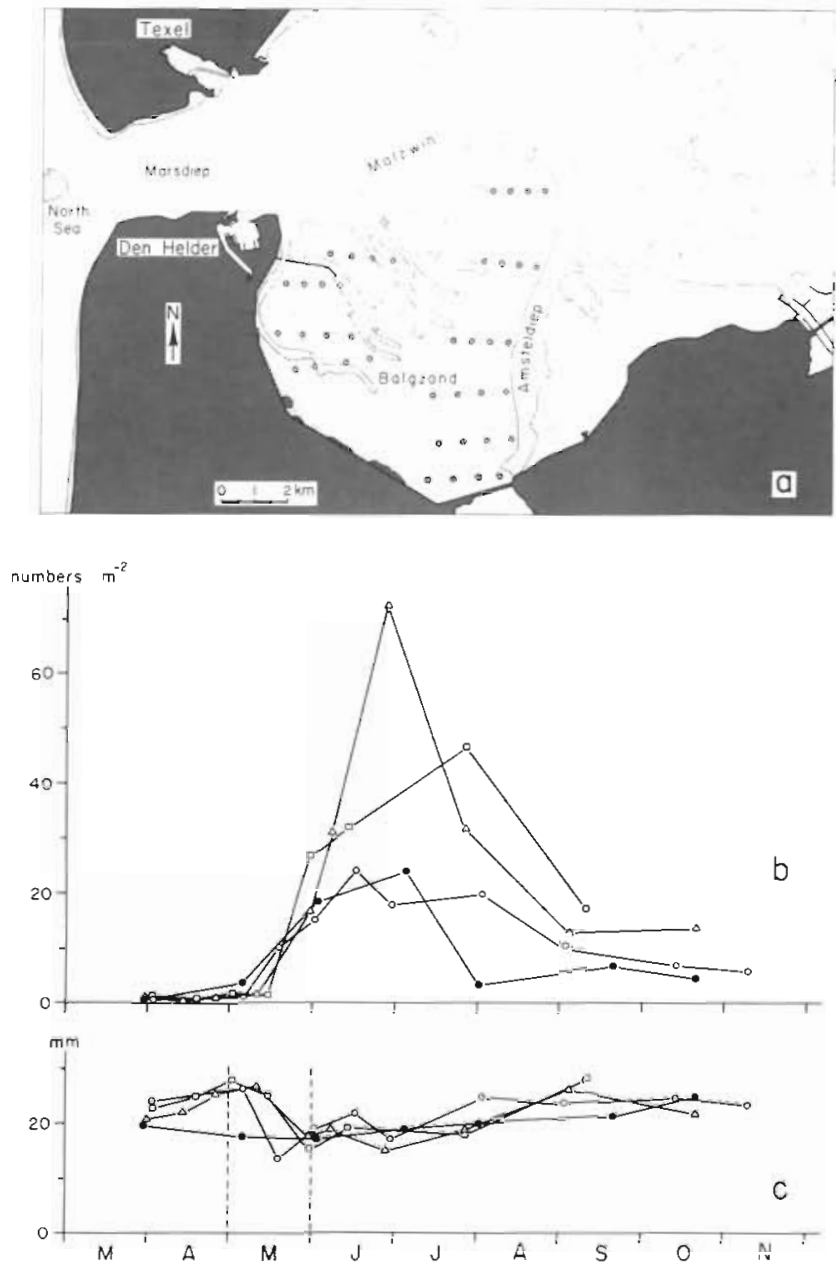

Fig. 1. (a) Map of Balgzand tidal flats (shaded area is intertidal) with $40 \mathrm{HW}$ sampling stations; (b) average density of the total Crangon crangon population on Balgzand; (c) mean length of $C$. crangon: $O 1976 ; \bullet 1977 ; \triangle 1978 ; \square 1979$

mortality in young plaice (Zijlstra et al. 1982). By comparing length-distributions at time $t_{2}$ with simulated length-compositions obtained from the lengthdistribution at time $t_{1}$ and growth rate during period $t_{1}-t_{2}$, changes in the abundance of various length groups, due to settlement or immigration and mortality or emigration can be estimated (Kuipers and Dapper, 1981). When, with the aid of length-weight relations, biomasses are calculated for all individuals that gradually immigrate or leave the area during period $t_{-}-t_{2}, a$ production estimate is found in the difference between total biomasses entering and leaving.

The method requires the presence of a correct growth model; in our case this was determined experimentally. The application of experimental growth rates in simulating growth under natural conditions, implies that the shrimp's behaviour and feeding conditions in the aquaria should be comparable to those in the natural habitat. This, in turn, requires some know- 
ledge, e.g. on natural densities of prey through the seasons and actual availability of this food to feeding shrimp.

In order to meet these requirements, studies on the composition of stomach contents, densities of prey items in the field (van der Ark, 1981; Derks, 1980) as well as on food requirements (Janssen, 1980) were carried out. The actual densities of prey animals as measured in bottom cores turned out to be several magnitudes higher than the number of prey taken by young shrimp per $\mathrm{m}^{2}$ per year (van der Ark, 1981). Hence the shrimp's natural feeding conditions on Balgzand are assumed to be almost ad libitum.

Growth experiments with shrimp in aquaria with ad libitum ratios of a mixture of natural prey items led the following Crangon crangon growth model of length increase $y\left(\mathrm{~mm} \mathrm{~d}^{-1}\right)$ as a function of water temperature $\mathrm{T}\left({ }^{\circ} \mathrm{C}\right)$ and body length $\mathrm{L}(\mathrm{mm})$ :

$$
y=0.1625+0.01025 \mathrm{~T}-0.00403 \mathrm{~L}
$$

When this simple model, which gives the average length increase, is used to calculate growth of young

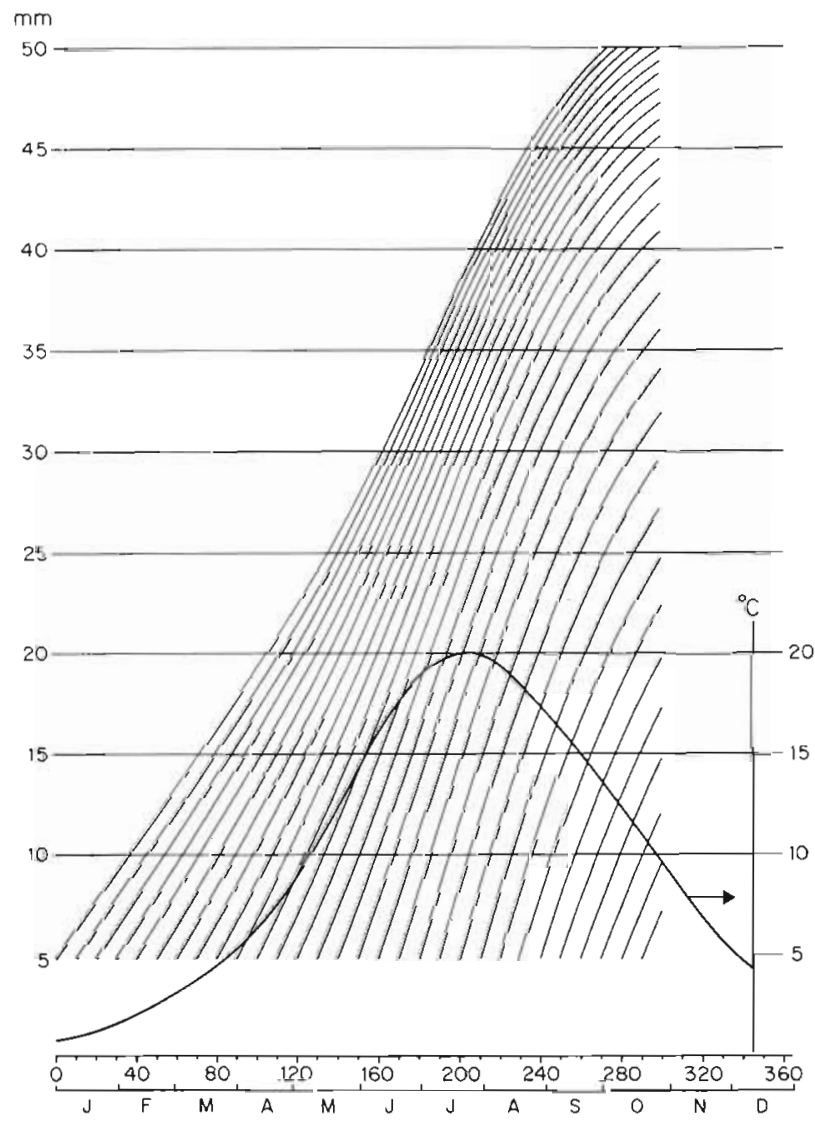

Fig. 2. Crangon crangon. Simulated growth curves on Balgzand tidal flats, starting at $4.7 \mathrm{~mm}$ every 10 th day and increasing according to experimental results of $\mathrm{M}$. Fonds (unpubl.). Temperature curve: Balgzand HW temperature averaged over 4 ys shrimp on Balgzand, the simulated growth curves show a good correspondence with growth under natural conditions in the area, as far as this could be derived from the shift of recognizable peaks in successive length-frequency distributions (Kuipers and Dapper, 1981).

Although the experimental material contains some high values within its range of growth rates from 0.12 to $0.35 \mathrm{~mm} \mathrm{~d}^{-1}$, the average growth reflected in the present model - leading to a development time from ripe egg to shrimp longer than $52 \mathrm{~mm}$ of ca. $8 \mathrm{mo}-$ seems most acceptable since it explains the phenomena observed in the field rather well. Compared to literature data on growth of Crangon crangon, the simple model suggested here also quite satisfactorily predicts the average length at the end of the first growth season as given by different authors (Kuipers and Dapper, 1981).

Fig. 2 shows simulated growth curves of young shrimp on Balgzand starting every 10th day at a length of $4.7 \mathrm{~mm}$; these were computed on the basis of an averaged (4yr) and smoothed temperature curve.

In the following account, specific size groups of young shrimp - that according to our field data entered the tidal system in large numbers at the time of high input into the nursery - will be shifted along these growth curves in order to detect the times at which they most probably left the plankton at a length of $4.7 \mathrm{~mm}$, reached the subtidal phase at a length of $30 \mathrm{~mm}$, and finally reached maturation at a length of about $45 \mathrm{~mm}$.

\section{LIFE CYCLE OF CRANGON CRANGON IN THE WADDEN SEA}

\section{Settlement}

As shown by Kuipers and Dapper (1981) our method can be used to compute the input of small shrimp in the tidal flat area studied, where direct estimates of immigration on basis of the length-frequency distributions are impossible. According to Fig. 3, this input into the nursery is a more or less peakwise invasion of shrimp of the smallest three $0.5 \mathrm{~cm}$ length classes, comprising shrimp from 5 to $20 \mathrm{~mm}$. Since postlarval shrimp leave the plankton at a length of $4.7 \mathrm{~mm}$, the arrival of larger postlarval shrimps observed here can be explained in 2 different ways: (1) settlement occurs in an area much wider than the actual tidal flat surface, and small shrimp immigrate into the tidal zone somewhat later; or (2) settlement on tidal flats occurs at a size of $4.7 \mathrm{~mm}$, while the sampling method missed most of these early-stage settlers and started to record them in significant numbers somewhat later. In that 


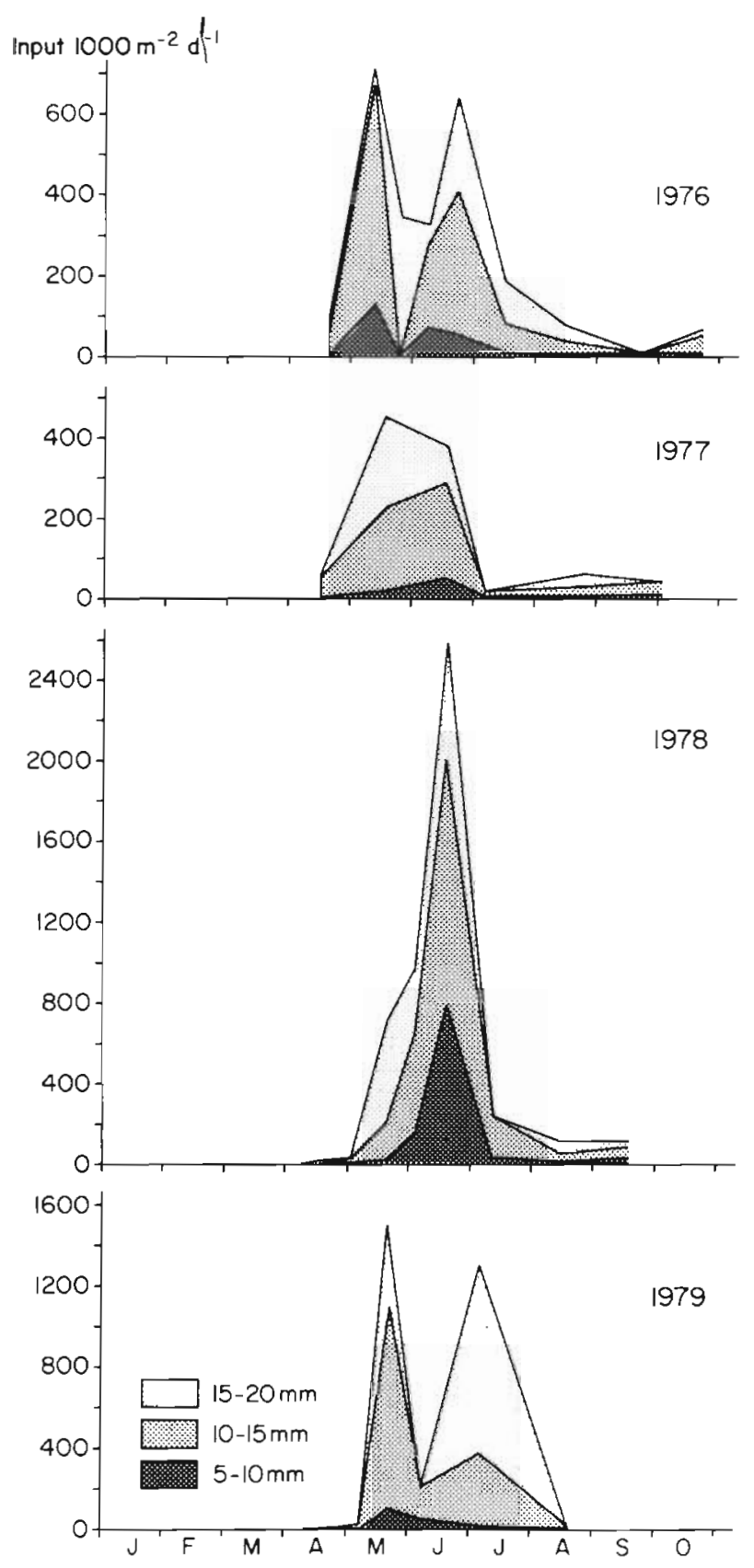

Fig. 3. Crangon crangon. Juveniles entering the Balgzand system $1000 \mathrm{~m}^{-2} \mathrm{~d}^{-1}$ as calculated in Kuipers and Dapper (1981)

case, immigration into the system should be explained as 'entering the catches', although the retention rates of the $5 \times 5 \mathrm{~mm}$ mesh-size trawl were rather significant even for the smallest length groups (Kuipers and Dapper, 1981).

Knowing the number of recruiting shrimps of different sizes (Fig. 3), the growth rate of these shrimps (Fig. 2 ) and the size at which settlement occurs $(4.7 \mathrm{~mm})$, it was possible to estimate the time period during which settlement occured. From these estimates, settlement curves as shown in Fig. 4 were compiled.

The main time of arrival of newly settling shrimp brood on the seabed indicated by this method starts with some year-to-year fluctuation - in February and is completed in August, the main settling period being March-June.

It should, in this context, be kept in mind that the figures for settlement or immigration into the nursery (input data derived from Kuipers and Dapper, 1981) are systematic under estimates. Newly settled shrimp will undoubtedly suffer from heavy predation and the number of postlarval shrimp entering the system and dying before the next sampling was carried out, escaped our observation. Especially the strong decrease in settlement from June-July onwards may partly be an artefact caused by increased mortality rates among new settlers rather than by a decreasing input of postlarval shrimp, as will be discussed later.

\section{End of nursery stage and completion of juvenile growth}

According to Janssen and Kuipers (1980) and Kuipers and Dapper (1981) juvenile shrimp leave the tidal nursery and invade the subtidal at a length of 30 to $35 \mathrm{~mm}$. The times at which the waves of settlers (Fig. 3) are ready to leave the tidal flats, at a length of $30 \mathrm{~mm}$, were estimated from the growth curves of Fig. 2, and presented in Fig. 4.

In general, significant numbers of spring juveniles begin to reach the subtidal stage in the beginning of July, with a maximum in August, whereas in September most of the new shrimp generation has already passed the nursery stage.

Assuming that the experimental growth rates for the nursery stage are useful estimates also for subsequent juvenile growth in the subtidal, the peaks of immigrating shrimp were shifted further until the length of $45 \mathrm{~mm}$ was attained (Fig. 4). During the years of observation, the first significant numbers of juveniles reach this length at the end of September.

Since Crangon crangon females mature at a length of $45 \mathrm{~mm}$ (Tiews, 1970; see also Fig. 5), the wave of shrimp brood settling in the nursery early in spring will reach maturation by the end of the year. When this new shrimp generation spawns during NovemberFebruary, carries eggs for ca. 13 wk (Lloyd and Yonge, 1947), and, finally, when the larvae stay for another $5 \mathrm{wk}$ in the plankton (Ehrenbaum, 1890), the next generation of settling larvae must be expected during March-May (Fig. 4). We may therefore conclude that between maturation and actual winter spawning, there is a time lag of several weeks. During October- 

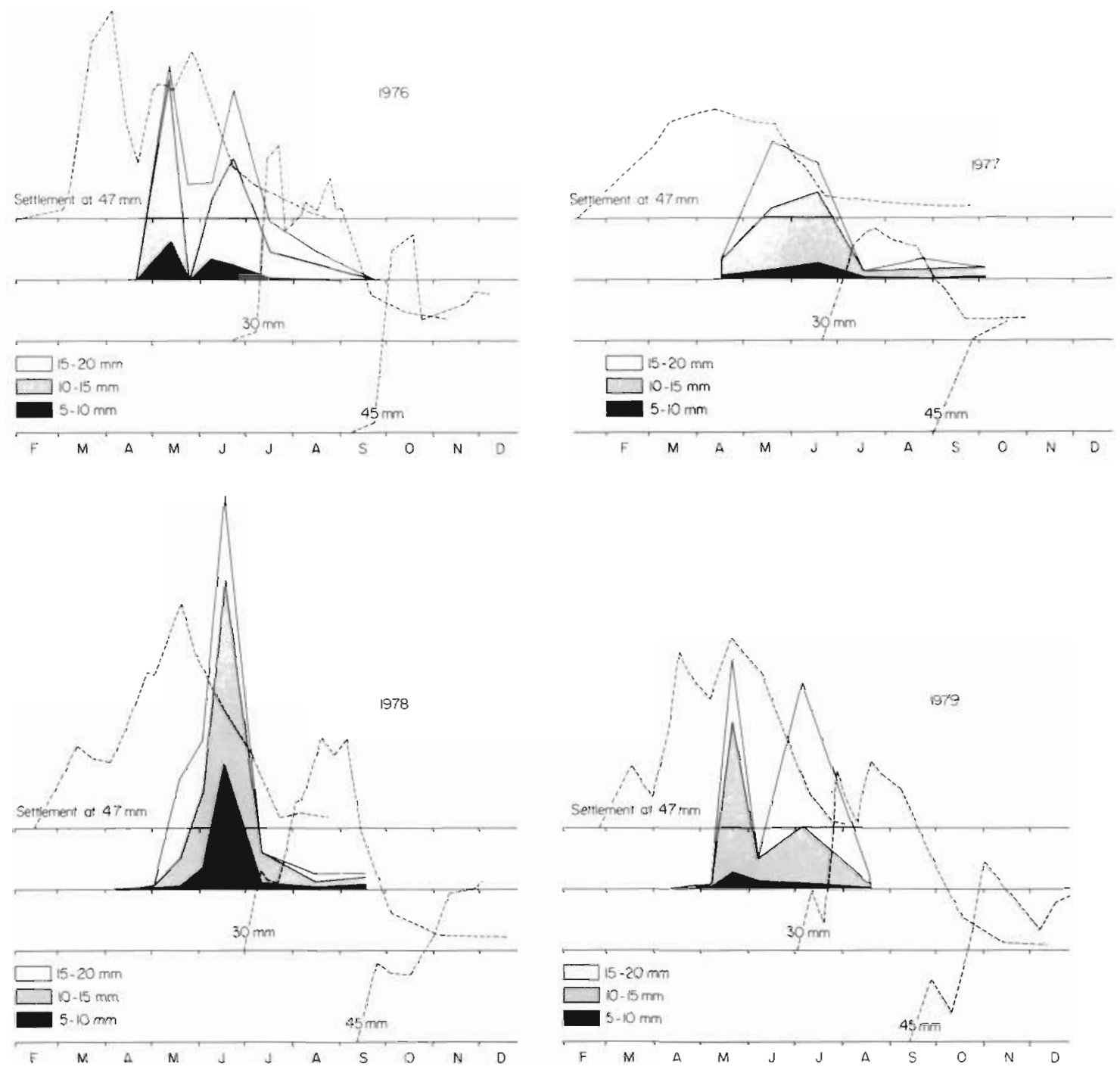

Fig. 4. Crangon crangon. Growth of juveniles in the nursery during 4 yr of observation. Groups of entering juveniles (Fig. 3) were shifted along the growth lines of Fig. 2, to points where they had attained length of $4.7,30$ or $45 \mathrm{~mm}$. Shifts were made irrespective of mortality. Note that the curves indicate numbers of shrimp reaching different lengths $1000 \mathrm{~m}^{-2} \mathrm{~d}^{-1}$

November the percentage of mature females bearing eggs is minimal; thereafter they show a marked spawning peak in January and February (Tiews, 1970; see also Fig. 5). Aithough there is lack of direct evidence, there can be little doubt that the onset of spawning early in the year is being synchronized by a seasonal trend of ambient factors, which keeps the $C$. crangon reproduction cycle in phase with the optimal annual growth period in our coastal waters in terms of temperature and food conditions.

\section{Subtidal shrimp data}

Can the annual Crangon crangon cycle, as deduced from data on its intertidal stage, be fitted into our knowledge of population dynamics in the subtidal area as reported by different authors? This question is difficult to answer because most data available on shrimp has been collected with trawls with cod-end mesh sizes of ca. $20 \mathrm{~mm}$ full mesh, twice as large as used in our data set. However, van Leeuwen (1975) and Creutzberg (1979) provided C. crangon data for the Dutch part of the coastal North Sea for 80 stations deeper than ca. $7 \mathrm{~m}$, collected by a trawl with a codend mesh size of $5 \times 5 \mathrm{~mm}$, similar to that used by us on the tidal flat. As Fig. 5 shows, the $C$. crangon population in that area is supplemented by a peak of juveniles of ca. $30 \mathrm{~mm}$ around July. These recruits obviously arrived from shallower areas and were not yet present in waters of more than $7 \mathrm{~m}$ depth in May. The average body size of the peak of juveniles and the time at which they join the adult population coincide with the time and size of the main output from the tidal 

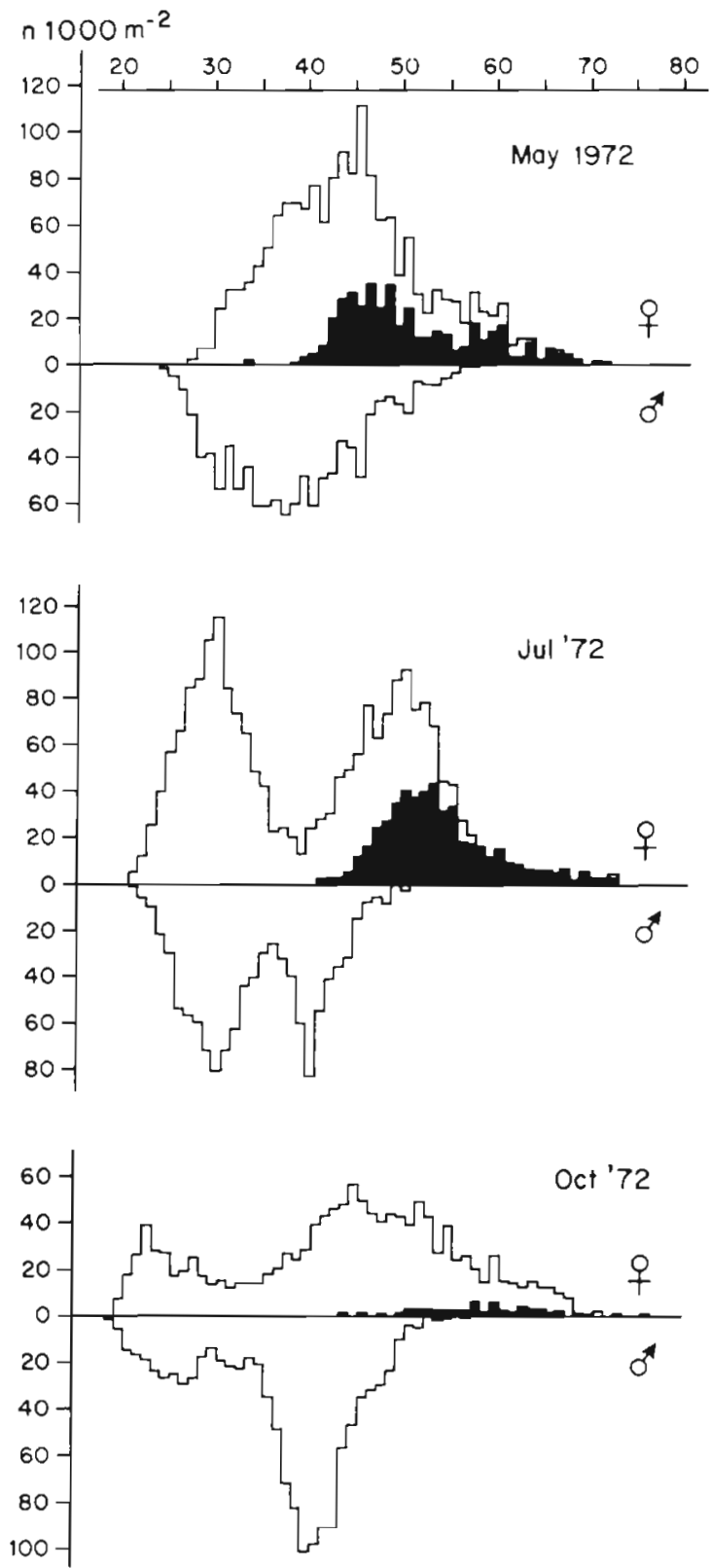

Feb $^{\prime} 73$

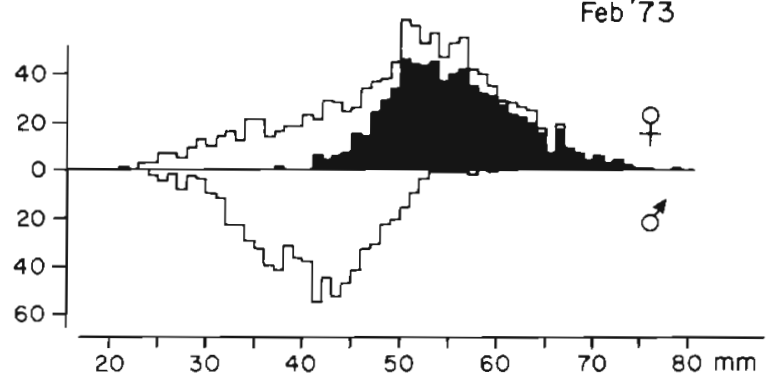

Fig. 5. Crangon crangon. Average length-distributions of the population in the coastal North Sea, expressed in numbers $1000 \mathrm{~m}^{-2}$ for each $\mathrm{mm}$ length class (after van Leeuwen, 1975). Upwards: females, shaded with eggs. downwards: males. The material was collected during Aurelia cruises covering 80 stations in the Southern North Sea (Creutzberg, 1979)
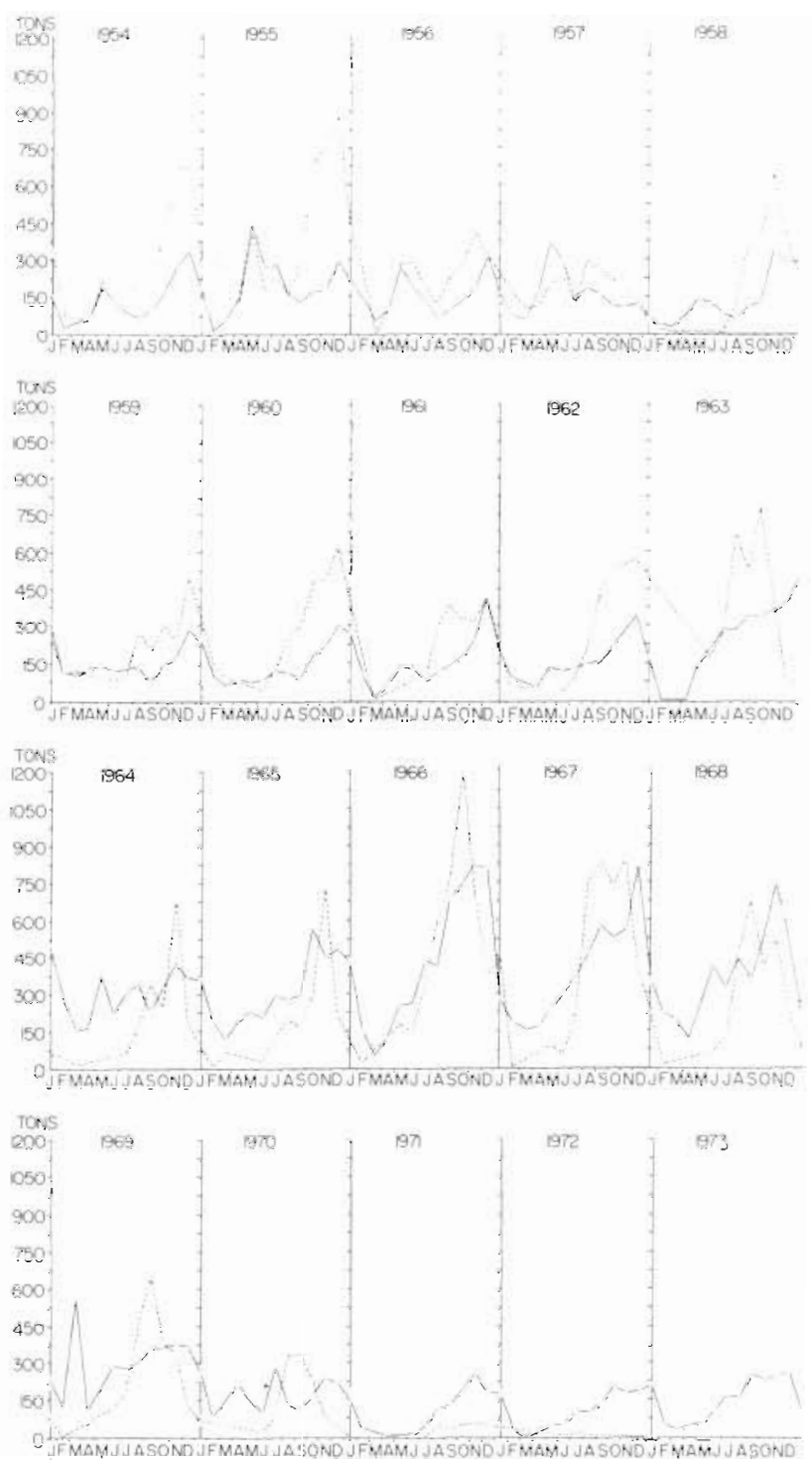

Fig. 6. Seasonal distribution of shrimp landings in the Dutch Wadden Sea 1954-1973, as given in 'Visserij-Nieuws' of the Dutch Ministry of Agriculture and Fisheries. Solid lines 'edible' shrimp; broken lines: 'industrial' or undersized shrimp

nurseries inside the Wadden Sea. Moreover, the rate at which the peaks grow fits nicely to our experimental growth lines (Fig. 2). Thus, the North Sea data indicata an annual cycle that runs in phase with that inside the Wadden Sea.

According to the $30 \mathrm{~mm}$ curves in Fig. 4 , the annual migration of juvenile shrimp from the nurseries towards the subtidal occurs mainly during July, August and September. This mass movement is reflected in the yearly catch of 'industrial' (undersized) shrimp in the Dutch Wadden Sea, that until about 1970 were landed and used as feed. Fig. 6 shows that this catch of undersized shrimp in general increased 

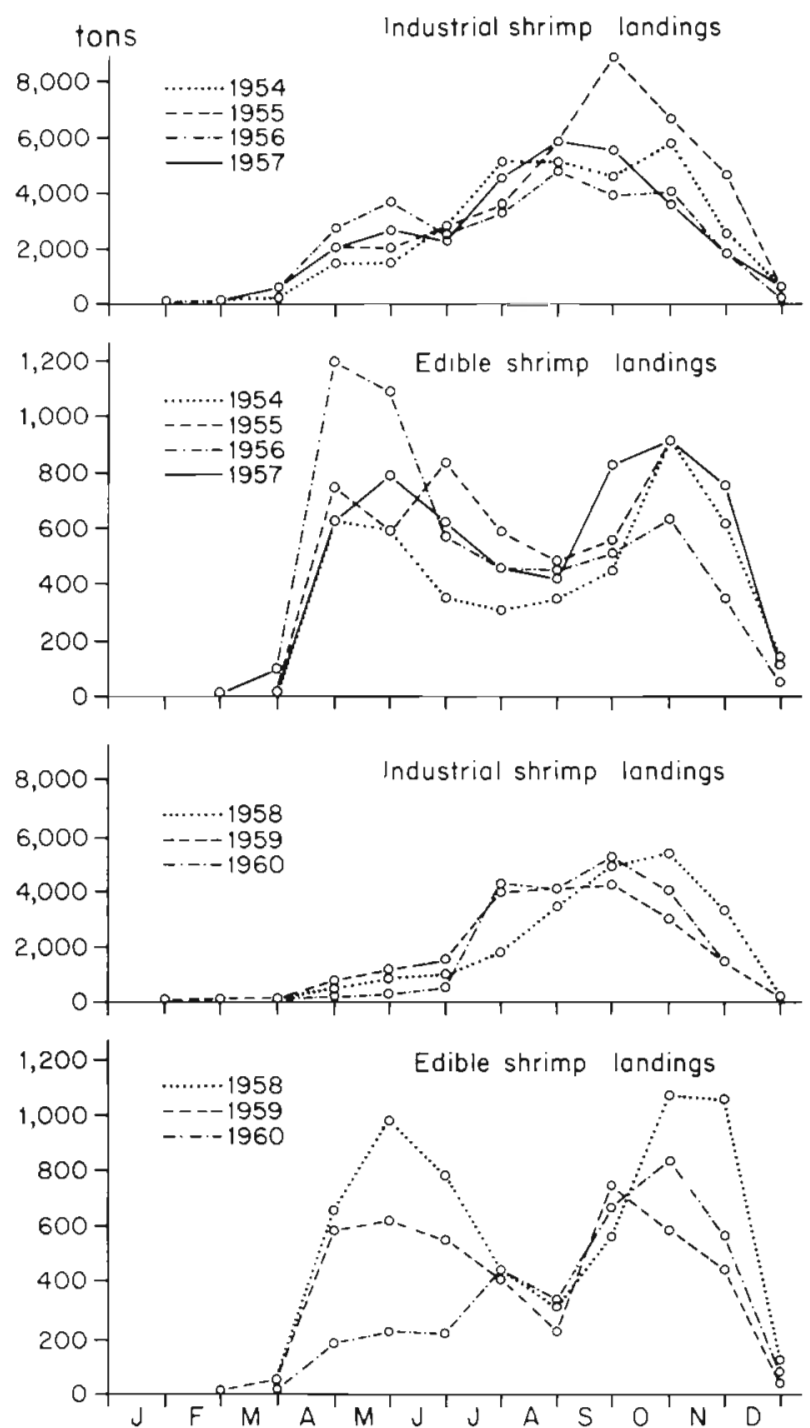

Fig. 7. Seasonal distribution of German shrimp landings 1954-1960 (after Meyer-Waarden and Tiews, 1965)

strongly during July-September. Data on the German shrimp fishery (Meyer-Waarden and Tiews, 1965) show this pattern even more clearly (Fig. 7). The catch of 'small-sized shrimp' in German waters increases also during July-September, and while it diminishes after these months, the catch of the larger 'edible' shrimp increases during September and October. This illustrates the shift of subtidal juveniles into the category of 'edible' shrimp (>52 mm) in late summer.

Shrimp fisheries data for the western Wadden Sea (Boddeke and Becker, 1979), where the Balgzand tidal flats represent a main nursery, also fit the pattern discussed so far. The landings of edible shrimp per fishing day in Den Oever show a yearly maximum in October-November, which is the period when according to our nursery data the young Crangon crangon generation, 2 mo after completion of its nursery stages, reaches the length of $50 \mathrm{~mm}$.

Therefore, the shrimp catches during the last months of the year must involve mainly the generation that originates from winter eggs, grows up in shallow areas during spring and early summer, and recruits towards fishery in autumn.

\section{DISCUSSION}

\section{Summer eggs and larvae}

The life cycle of Crangon crangon in the western Wadden Sea, discussed here so far, seems to depend fully on winter-egg production. C. crangon females are known, however, to produce considerable masses of eggs also during summer (Tiews, 1970; Boddeke, 1976). According to Boddeke and Becker (1979) and Boddeke (1982) the main reproduction takes place during summer, with June, July and August being the months with maximum numbers of ripe eggs. According to this view, growth from ripe eggs to shrimp longer than $52 \mathrm{~mm}$ lasts 4 mo in summer; this means an average growth rate of at least $0.40 \mathrm{~mm} \mathrm{~d}^{-1}$. Such rate is in contrast to the average growth rate of $0.23 \mathrm{~mm} \mathrm{~d}^{-1}$ observed on Balgzand (Kuipers and Dapper, 1981).

However, Boddeke's (1982) growth estimate is principally based on correlations between peaks in summer-egg production and the autumn shrimp yield, that were highest at a time shift of 4 mo (Boddeke and Becker, 1979). Except for the fact that the mass of juvenile shrimp invades tidal nurseries before the start of the summer spawning season (Fig. 1) - and hence autumn shrimp catches originate mainly from winter eggs - the fast growth rates implied by Boddeke's hypothesis, are not supported by our experimental data.

Moreover, in his study on seasonal migration Boddeke (1976) showed that the autumn migration of Crangon crangon towards its overwintering grounds is more pronounced in berried females than in the rest of the population, resulting in high percentages of berried females outside the Wadden Sea in winter, and their complete absence on the innermost stations around Den Oever. This may explain the contradiction between 'egg-landing' curves for Den Oever with a pronounced winter minimum as given by Boddeke and Becker (1979) and the Aurelia cruise data (Fig. 5) of the southern North Sea where the February samples gave the highest number of berried females per $1000 \mathrm{~m}^{2}$. If during summer and winter the percentages of berried C. crangon females are about equal, the total amount of eggs will in the first place be determined by the actual adult population size. The life cycle of C. crangon, with recruitment to the mature stock in autumn and a maximum adult population size in winter would then indicate the winter as the main reproductive sea- 
son. The ratio between the mature stock in April and that in October is ca. 1:6 (Boddeke, 1982). This would imply that winter spawning after October, when recruitment still raises the adult population level, must be at least 6 times as important as summer spawning by the adult female population present in April.

According to Boddeke (1982) winter eggs have a 1.16 times larger diameter $(0.43 \mathrm{~mm})$ than summer eggs $(0.37 \mathrm{~mm})$. The body-length/egg-number relation given by the author results for a 50 mim long female to a 1.55 times higher egg number in summer (2795) than in winter (1806). This means that in terms of total numbers, winter spawning should yield about 4 times as many eggs as summer spawning.

Although main egg production may be in winter, summer spawning around June and July must definitely lead to a significant settlement of postlarval Crangon crangon in the shallow nurseries later in summer. According to Balgzand tidal nursery data, main net settlement of $4.7 \mathrm{~mm}$ postlarval shrimp occurs during March-May (Fig. 4). During summer, from June onwards, net settlement of larvae was estimated to be low.

Since net settlement is calculated on the basis of fortnightly Balgzand surveys, settlers which arrive and

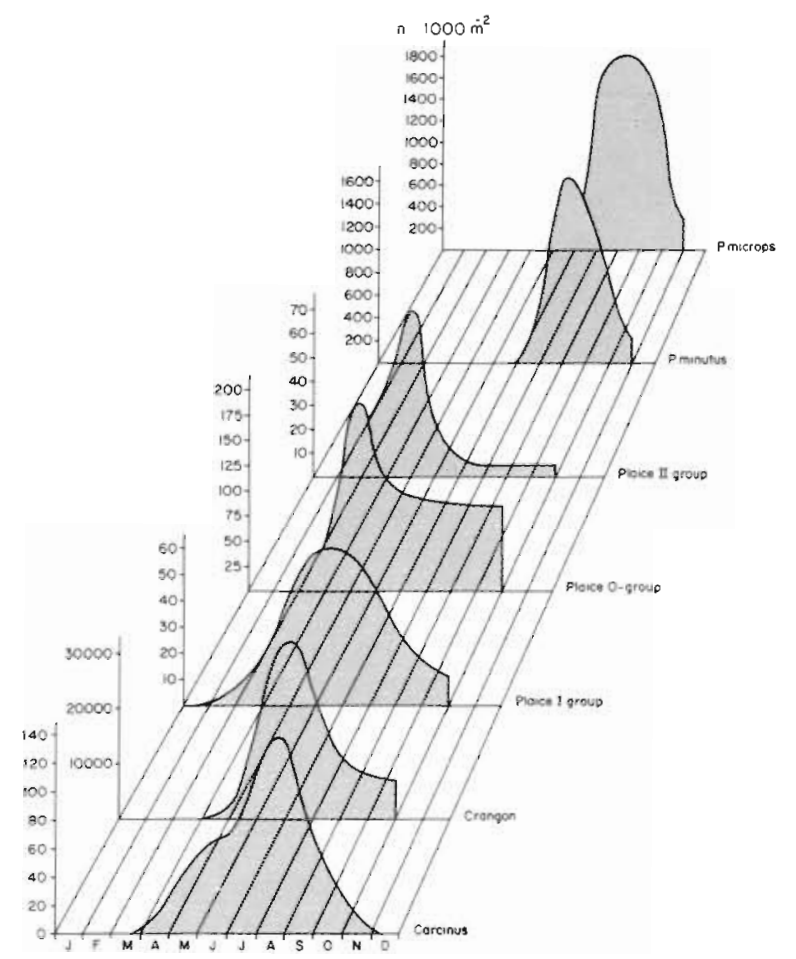

Fig. 8. Seasonal population curves (numbers $1000 \mathrm{~m}^{-2}$ ) of different carnivore populations on Balgzand tidal flats (Pomatoschistus microps and P. minutus from van Beek, 1976: 2 ys: Plaice $0^{-}, \mathrm{I}^{-}$and II-group from Kuipers, 1977: 4 ys; Crangon crangon from Kuipers and Dapper, 1981: 4 ys; Carcinus maenas from Afman, 1980: 2 ys die within the period between 2 surveys are actually excluded from our observation (Kuipers and Dapper, 1981). A possible increase in mortality of summer settlers on Balgzand can, therefore, explain the unexpectedly low net summer settlement observed. Maximum net input in spring is in the order of 500 to 2500 postlarval shrimp $1000 \mathrm{~m}^{-2} \mathrm{~d}^{-1}$; even if this rate of settlement would last the whole summer, and not be reduced to $1 / 4$ of its spring value, an extra average predation of 0.5 to 2.5 settlers $\mathrm{m}^{-2} \mathrm{~d}^{-1}$ from June onwards would be sufficient to wipe out the net summer settlement in the nursery.

Fig. 8 shows the population curves of different possible Crangon crangon predators on Balgzand tidal flats in the course of the year. While at the end of June the 3 age groups of plaice Pleuronectes platessa and young C. crangon show a population decline, Carcinus maenas - and especially Pomatoschistus microps and $P$. minutus - build up their populations with rapidly growing new age groups on the tidal flats. Especially for the latter 2 species, young shrimp are a favourable food item; they may therefore be responsible for the destruction of shrimp brood during June-December (van Beek, 1976, Tiews, 1978). Fig. 9 presents a tenta-

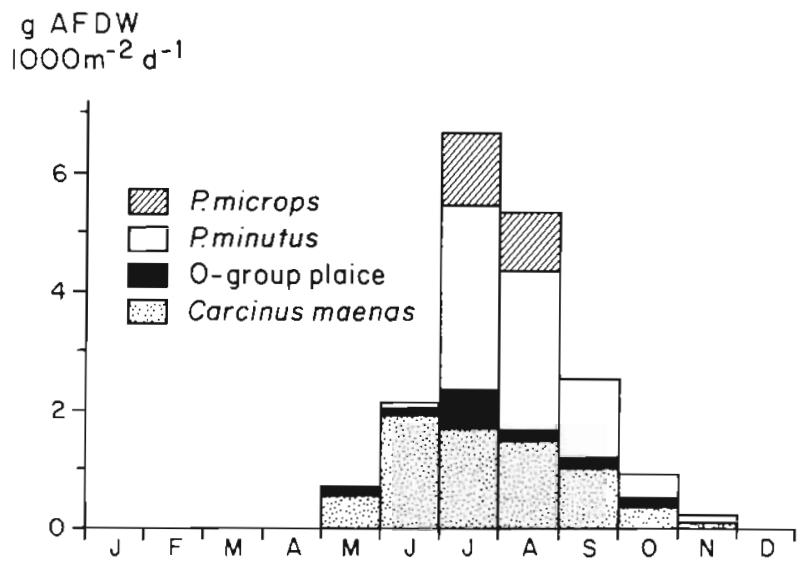

Fig. 9. Consumption of small Crangon crangon by the predator populations listed in Fig. 8 (g AFDW $1000 \mathrm{~m}^{-2} \mathrm{yr}^{-1}$ ). Consumptions were calculated on the basis of literature referred to in Fig. $8.1 \mathrm{~g}$ AFDW equals about 2000 shrimp averaging $6.6 \mathrm{~mm}$ (average length during first $14 \mathrm{~d}$ after settlement) weighing ca. $0.5 \mathrm{mg}$ AFDW each

tive estimate of the total mass of young $C$. crangon eaten by collective benthic predators on Balgzand. The figure shows an increase in predation around midsummer which may explain the decrease in net shrimp settlement discussed so far.

Since shrimp settling during summer on Balgzand are, apparently, subjected to almost complete destruction by predators, the question arises how the population maintains the wasteful habit of summer reproduction 


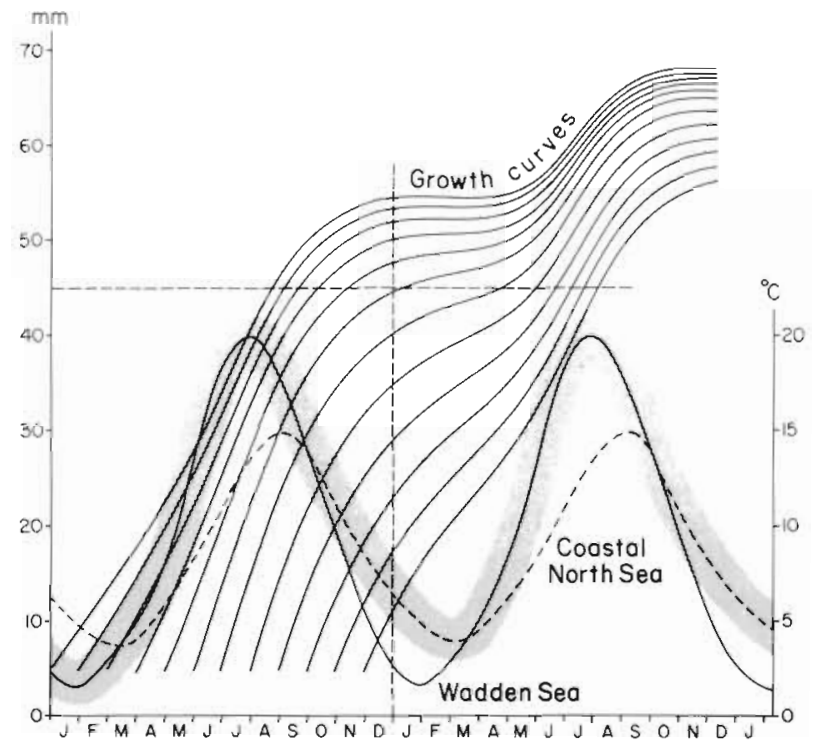

Fig. 10. Crangon crangon. Simulated growth curves in Dutch coastal waters, starting at $4.7 \mathrm{~mm}$ every month, and increasing during two successive growth-seasons. Temperature curves: solid line Wadden Sea; broken line coastal North Sea; shaded area includes parts of the two temperature curves used in calculating growth-rates

A possible explanation for the seemingly unfunctional occurrence of a considerable amount of berried Crangon crangon females in summer is presented in Fig. 10. Here, growth in postlarval shrimp, entering the system all year round, was simulated with the experimental growth model. Since $C$. crangon tends to leave the estuary for the coastal North Sea in autumn and to return to the Wadden Sea in spring, average North Sea temperatures (Fonds, 1978) instead of Wadden Sea temperatures, were used from October till March in the calculation of growth. This is in accordance with Havinga (1930), who explained the seasonal migration in C. crangon as a search for the warmest water masses available - a view emphasized by Spaargaren (1980). Fig. 9 shows a considerable decrease in growth during winter, especially in larger juveniles. The figure illustrates that through this delay in growth during winter, settling shrimp arriving in the nursery between February and September will be divided into 2 groups when reaching maturation. The majority of the settlers arriving before June will reach $45 \mathrm{~mm}$ during SeptemberDecember, whereas those arriving after June will not reach this length before May of the following year. Although the reproductive success of the latter group may be low, the $C$. crangon population will always produce a certain amount of new summer spawners, even if each shrimp spawns only once a year. Summer spawning will not be exclusively a matter of the juveniles that overwinter as pre-adults, because repeated spawning in the older generations takes place as well (Meixner, 1966). Since, however, annual population fluctuations seem to be dominated by the massappearance of the youngest generation, it will most probably be also the recruits that have the main share in egg production.

\section{Reproductive strategy}

The present simulations suggest that the life cycle of Crangon crangon in the western Wadden Sea is mainly controlled by the effect of seasonal temperature fluctuations on juvenile growth. Differences in the shrimp annual cycle along the continental coasts of Europe can be explained that way too.

Fig. 11 shows spawning seasons at different latitudes (Tiews, 1970). In the south, along the Mediterranean coast, spawning is observed exclusively during the coldest months of the year (Labat, 1977). Here the length of the growth season (April-November) and temperature cycle (with a maximum of $24^{\circ} \mathrm{C}$ in July) obviously allow all juveniles to mature at the end of their first year and no exception from the single-winter spawning life cycle is observed

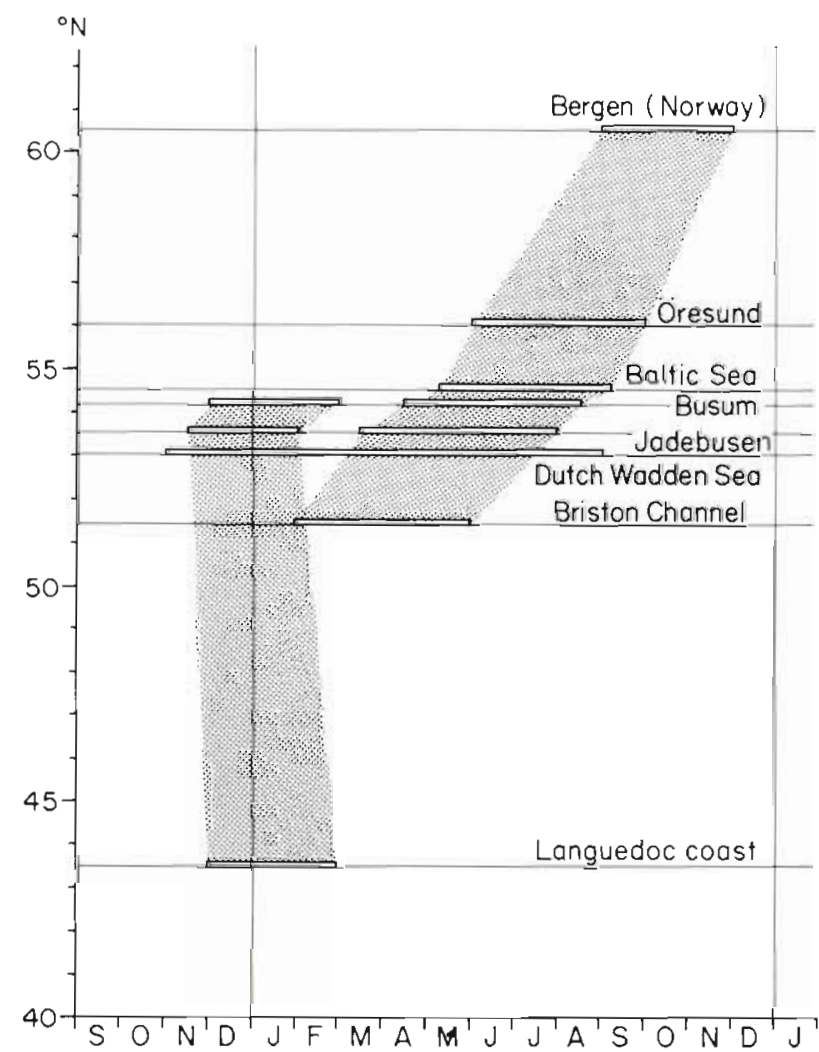

Fig. 11. Crangon crangon. Spawning seasons (horizontal bars) of populations along the European coasts, according to literature data reviewed in Tiews (1970). Shaded areas: fixed winter spawning season and shifting summer spawning 
At the opposite end of the continuum, in the north, spawning occurs exclusively in summer and autumn: during May-September in the Oresund and during August-December at Bergen (Norway). Lower temperatures will result in lower growth rates during the relatively short summer. Juvenile development will take somewhat more than 1 growth season in the Oresund, to most likely 2 complete seasons in Norway, before the first spawning takes place.

In the intermediate area, both the northern and the southern reproductive cycle seem to occur. From south to north within this area, there appears to be a slight shift with most emphasis on winter spawning in the Dutch Wadden Sea, to gradually more weight on summer reproduction along the German and the Danish coasts. Going north, the fraction of juveniles that does not reach maturation within 1 growth season gradually increases.
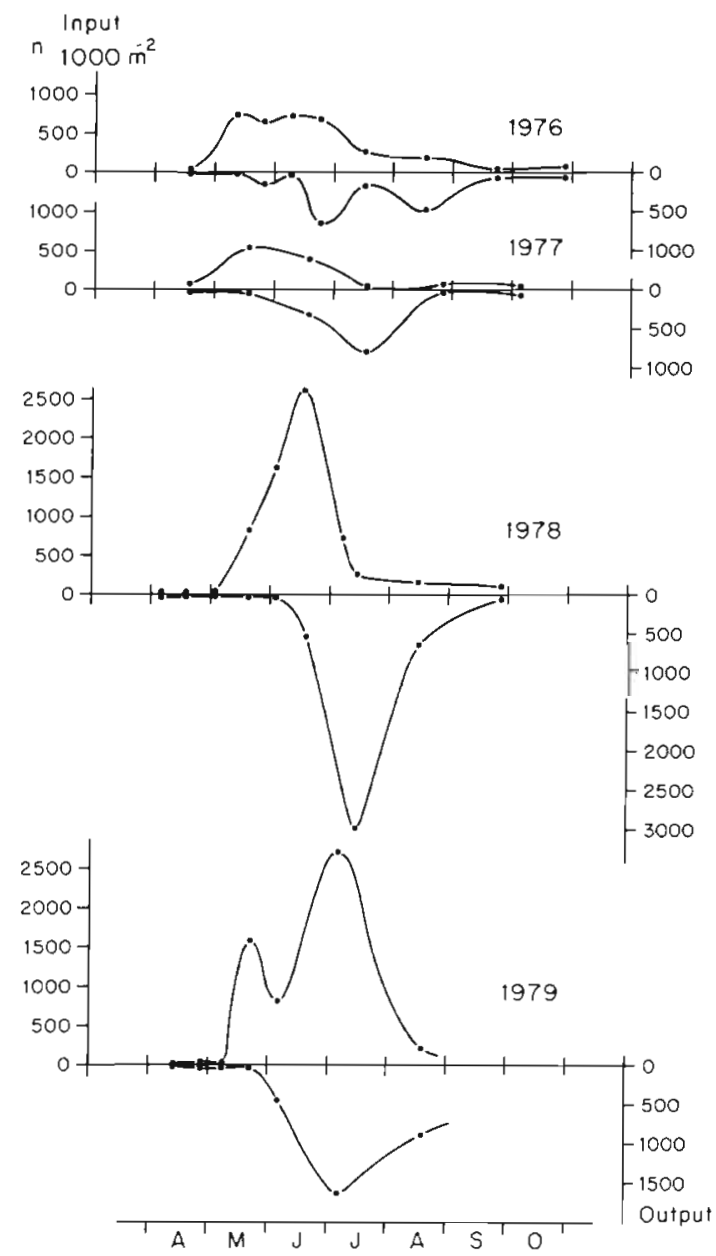

Fig. 12. Crangon crangon. Input (upward) and output (downward) of shrimp, as calculated for the Balgzand system (numbers $1000 \mathrm{~m}^{-2} \mathrm{~d}^{-1}$; Kuipers and Dapper, 1981). Note, that output curves represent both emigration and mortality in all size groups

\section{Local change in shrimp harvest}

On the basis of Balgzand data, it appeared that shrimp catches during the following year are predictable to a certain extent from the numbers of subadult juvenile shrimp leaving the shallow nurseries. Although the estimation of this output requires regular surveys in the nursery (in our waters during June-August) - and hence is a quite laborious measurement the Balgzand data of successive years given in Kuipers and Dapper (1981) showed that predictions are possible.

As discussed in the present paper, the nurseries output enters the fisheries during autumn and leads to increasing catches until the end of the year. After movement to overwintering grounds, the rest of this generation is available to the fisheries in spring of the following year, until about the time the new generation shows up and starts dominating the catches. On the basis of Balgzand output data shown in Fig. 12, one should expect a low catch in autumn 1976, in spring 1977, in autumn 1977, and in spring 1978.

In autumn 1978 recruitment should be much larger, so that the catches then, and in spring 1979 should be higher. Finally, in autumn 1979 and in spring 1980 there should be again high catches, which makes 1979 and 1980 years with higher catches than during the 2 years before. Such a state of affairs has indeed been confirmed by the shrimp landings in Den Oever, near the Balgzand (Boddeke, 1982).

Acknowledgements. We thank J. IJ. Witte and all others involved in the Balgzand sampling programme; Dr. M. Fonds, for kindly allowing us to use his experimental shrimp data; Professor K. Tiews, Dr. J. J. Zijlstra and especially, Dr. F. Creutzberg for critical appraisals of the manuscript.

\section{LITERATURE CITED}

Afman, B. P. (1980). De voedselopname van de strandkrab Carcinus maenas (L). NIOZ Intern. Reports 1980-4

Ark, P. v. d. (1981). De samenstelling van het voedsel en de consumptie van jonge garnalen (Crangon crangon L.) op een wadplaat in de westelijke Waddenzee. NIOZ Intern. Reports 1981

Beek, F. A. v. (1976). Aantallen, groei en voedselopname van de zandgrondel ( $P$. minutus) en de wadgrondel ( $P$. microps) op het Balgzand. NIOZ Intern. Reports 1976-9

Boddeke, R. (1976). The seasonal migration of the brown shrimp Crangon crangon. Neth. J. Sea Res. 10(1): 103-130

Boddeke, R. (1982). The occurence of winter and summer eggs in the brown shrimp (Crangon crangon) and the pattern of recruitement. Neth. J. Sea Res. 16: 151-162

Boddeke, R., Becker, H. B. (1979). A quantitative study of the fluctuations of the stock of brown shrimp (Crangon crangon) along the coast of the Netherlands. Rapp. P.-v. Réun. Cons. perm. int. Explor Mer 175: 253-258

Creutzberg, F. (1979). 'Aurelia'-cruise reports on the benthic 
fauna of the southern North Sea - Introductory Report NIOZ Intern. Reports 1979-4

Derks, P. (1980). Kwantitatieve bepaling van de dagelijkse voedselopname van garnalen (Crangon crangon L.). NIOZ Intern. Reports 1980

Ehrenbaum, E. (1890). Zur Naturgeschichte von Crangon vulgaris Fabr. Berlin, Dtsch. Seefisch.-Verein, Mittl. Sekt. Küsten-u. Hochseefisch., Sonderbeilage: 9-124

Fonds, M. (1978). The seasonal distribution of some fish species in the western Dutch Wadden Sea. In: Dankers, Wolff and Zijlstra (ed.) Fishes and fisheries of the Wadden Sea. Report 5 of the Wadden Sea working group: 42-77

Havinga, B. (1930). Der Granat (Crangon vulgaris Fabr.) in den holländischen Gewässern. J. Cons. perm. int. Explor Mer 5: 57-87

Janssen, G. M. (1980). De voedselopname van de garnaal Crangon crangon (L.). NIOZ Intern. Reports 1980-3

Janssen, G. M., Kuipers, B. R. (1980). On tidal migration in the shrimp Crangon crangon. Neth. J. Sea Res. 14(3-4): $339-348$

Kuipers, B. R. (1977). On the ecology of the juvenile plaice on a tidal flat in the Wadden Sea. Neth. J. Sea Res. 11(1): $56-91$

Kuipers, B. R., Dapper, R. (1981). Production of Crangon crangon in the tidal zone of the Dutch Wadden Sea. Neth. J. Sea Res. 15(1): 33-53

Labat, J-Ph. (1977). Ecologie de Crangon crangon (L.) (Decapoda, Caridea) dans un etang de la côte Languedocienne I. - croissance, reproduction, migrations mer/etang. Vie Milieu, Serie A, 27 (2a): 273-292

Leeuwen, F. van (1975). Verspreiding van verschillende garnalen soorten in de zuidelijke Noordzee gedurende verschillende seizoenen. NIOZ Intern. Reports 1975-8

Lloyd, A. J., Yonge, C. M. (1947). The biology of Crangon vulgaris in the Bristol Channel and the Severn estuary. J. mar. biol. Ass. U. K. 26: 626-661

Meixner, R. (1966). The effects of food supply on moulting, growth and spawning of the shrimp Crangon crangon (L.).
ICES, C. M. Shellfish Committee, M: 5: 1-7

Meyer-Waarden, P. F., Tiews, K. (1957). Krebs- und Muscheltiere. I. Teil. Krebstiere by K. Tiews. Arb. dt. Fisch. Verb. (8) : $1-56$

Meyer-Waarden, P. F., Tiews, K. (1965). Der Beifang in den Fängen der deutschen Garnelenfischerei in den Jahren 1954-1960. Ber dt. wiss. Komm. Meeresforsch. 18(1) $13-78$

Redant, F. (1978). Konsumptie en produktie van post-larvale Crangon crangon (L.) (Crustacea, Decapoda) in de Belgische kustwateren. Thesis, Vrije Universitiet Brussel, 1978

Spaargaren, D. H. (1971). Aspects of the osmotic regulation in the shrimps Crangon crangon and Crangon allmanni Neth. J. Sea Res. 5(3): 275-333

Spaargaren, D. H. (1980). The significance of seawater viscosity for the tidal transport of common shrimps Crangon crangon (L.). Ophelia 19(2): 145-153

Tiews, K. (1954). Die biologischen Grundlagen der Büsumer Garnelenfischerei. Ber. dt. Komm. Meeresforsch. 13(3): 235-269

Tiews, K. (1970). Synopsis of biological data on the common shrimp Crangon crangon (Linnaeus, 1758). FAO Fisheries Reports No. 57, vol 4.: 1167-1224

Tiews, K. (1978). Predator-prey relationship between fish populations and the stock of brown shrimp (Crangon crangon L.) in German coastal waters. Rapp.. P.-v. Reun. Cons. int. Explor. Mer 172: 250-258

Verwey, J. (1956). A plea for the study of temperature influence on osmotic regulation. Ann. Biol. 33(3-4): 129-149

Verwey, J. (1958). De seizoensverplaatsingen van enkele schaaldieren en de invloed van temperatuur en zoutgehalte. Kon. Ned. Akademie v. Wetensch. Versl. Afd. Natuurk. 67(1): 14-22

Zijlstra, J. J., Dapper, R., Witte, J. IJ. (1982). Settlement, growth and mortality of post-larval plaice (Pleuronectes platessa) in the western Wadden Sea. Neth. J. Sea Res. 15: 250-272

This paper was presented by Dr. J. J. Zijlstra; it was accepted for printing on February 21, 1984 